\title{
INDUSTRIAL HERITAGE AND PLACE IDENTITY IN SPAIN: FROM MONUMENTS TO LANDSCAPES*
}

\author{
PAZ BENITO DEL POZO and PABLO ALONSO GONZÁLEZ
}

\begin{abstract}
In Spain, the birth of interest in the nation's industrial heritage dates from the 1980 s and occurred alongside the process of deindustrialization. Policies concerning derelict industrial sites have shifted gradually from destruction to preservation, rehabilitation, and enhancement, and industrial heritage enhancement projects are now widespread in the country. However, a clear mismatching has arisen between institutional and academic initiatives and local communities, which exhibit widespread disinterest in or even rejection of industrial remains. This problematic situation can be related to the utilization of industrial heritage as an economic resource without paying much attention to its connections with memory and identity. Also, the mismatching is due to a positivist approach to industrial heritage whereby the monument and the museum are prioritized. We argue that projects which consider industrial remains as part of cultural landscapes might shorten the gap between the institutional and economic side of industrial heritage and its identity-building and popular facets. Keywords: cultural landscape, identity, industrial heritage, Spain.
\end{abstract}

O ld factories are still running!” exclaimed an Irish colleague who was visiting Pablo Alonso in the summer of 2011. Our friend's surprise points to one of the paradoxes that industrial heritage faces in Spain: Academic and institutional discourses and ideas about the enhancement of industrial remains can travel faster than the actual demise of their productive functions. Moreover, these discourses definitely spread more quickly than do feelings of nostalgia or emotional connection to industrial heritage among residents in nearby communities. These issues lead to some paradoxical situations in Spain. Should factories and mines be preserved just after the end of their productive functions? What should be kept for the future? How can preservation projects proceed amid widespread attitudes of rejection or indifference toward industrial heritage on the part of local communities?

Industrial heritage has been said to celebrate the lower classes' everyday material culture and way of life (Martínez and Closa 1999), a heritage of the people rather than for the people (Samuel 1994). Conversely, it has been suggested that heritage is always an affair of higher classes (Smith 2006). In fact, the lack of interest in industrial heritage among members of the Spanish working class is understandable. The "heritage affair" is broadly a feature of cultural agendas set by metropolitan middle- and upper-class interests and priorities. Furthermore, the lack of broader public engagement does not have much to do with the fact that not enough time has passed or that younger people-who will supposedly be nostalgic about remains of the past-have to replace the elder generations. Industrial

* This study was conducted as part of the National Scientific Research, Development, and Technological Innovation Plan, financed by the Spanish Ministry of Science and Innovation (CsO2010-18 471).

3. Dr. Benito Del Pozo is an assistant professor of geography at the University of León, Campus de Vegazana, 24071, León, Spain; [paz.benito@unileon.es]. Mr. Alonso González is a doctoral candidate in archaeology at the University of Cambridge, Cambridge, CB2 3DZ, U.K.; [pa332@cam.ac.uk]. 
heritage has thus been largely utilized as a future-oriented economic resource, neglecting emotional and popular potential for the generation of new identities and connections with the past. An exception to this concerns areas where the legacy of industry is connected with narratives of national or regional identity, such as in Catalonia or the Basque Country and, to a lesser extent, Asturias. Here, awareness concerning industrial heritage is far more developed than in other Spanish regions, and local engagement is more pronounced.

In this article we argue that both the mismatching between academic and institutional expectations and the utilization of industrial heritage as an economic resource entail a break with local communities and partially explain the lack of territorial and landscape approaches to the enhancement of industrial heritage. Heritage can only function as a self-fulfilling prophecy in economic terms when local communities are involved and feel connected to projects that aim to shift from a productive economy to a tourism-based one.

Furthermore, a naive and object-oriented approach to industrial sites prevails, in which the enhancement efforts focus on "industrial monuments" such as the old train, the factory, or the mining pit. Meanwhile, industrial territories are largely disregarded or merely represented in museum displays. We argue that evidence points to an incipient shift in industrial heritage practices in Spain, one that moves from the dyad museum-monument to a conception that considers it part of complex cultural landscapes, with significant implications for spatial planning and for the conceptualization of industrial heritage.

\section{From Factories to Services: \\ The Transition to a Postproductivist Economy}

Industrial heritage appeared as both a material by-product and a social construction thanks to the gradual advent of postproductivism in the most-developed economies after World War II. When conceived as a material remain with attached aesthetic values, it is linked to processes of territorial valorization resembling what has elsewhere been defined as the "becoming-rent of profit" (Harvey 2002; Vercellone 2008). When related to memory, community, and the past it connects with place identity. Both aspects are always present in "heritages" of all kinds and are always intertwined to a certain extent.

The productivist period that started with the Industrial Revolution in Great Britain in the eighteenth century entailed deterritorialization of the links between human communities and territories. The market and the enterprise, ordering factors of the territory, ascribed definite roles to space: extractive, residential, or industrial (Magnaghi 2005). Technical progress freed geographers and planners from the physical constraints of each area. Landscapes that were previously the outcome of an organic interaction between humans and nature were rationalized and tamed. However, the productivist order started to fade after World War II, especially during the 1970 s in the United States and Europe. Economies based on industry began to shift to service-based or knowledge economies (Fumagalli 2007). 
Central in this new era was the tendency of the financial sector to attain a prevailing role in the economy, followed by a depletion of the "real" or productive economy and a subsequent process of deindustrialization and delocalization of factories in peripheral countries (Marazzi 2010). If spatial planning and geographical practice reflect the ideology of each period (Gunder 2010), the new ideological motto of the period is the mixture of culture and leisure, as part of a new expansion and reinvention of capitalism (Thrift 2006).

This process started in Spain later than in core European countries such as Germany or Belgium, largely during the 1980 s and 1990s. Institutions were faced with the compelling problem of relocating or reinvigorating the decaying economies and shattered communities of industrial and mining areas. Many of those areas became marginal and started carrying out destructive activities such as producing energy, extracting, raw materials, or serving as dumps for urban areas. Other regions, such as Asturias, received huge subsidies to alleviate the disruptive effects of the industrial breakdown. However, most formerly industrial territories remained in no-man's-land, with rocketing unemployment and subsequent depopulation. For those areas, the logical transition to a postindustrial economy entailed the reinvention of tradition and a focus on tourism and the service sector.

It is thus understandable why in Spain such a strong emphasis is placed on industrial heritage as an instrument for economic reinvigoration: It was both the by-product of the deindustrialization process and a potential resource to help finding a way out of it. In this regard, industrial heritage could contribute to the "becoming-rent of profit" at the territorial level; that is, the service sector should thrive from a rent based on the aesthetic, physical, and human values of a definite territory. A hotel does not produce; it captures flows of tourism and investment attracted by a landscape, a service, or a monument. Industrial heritage would therefore sustain territorial value as an economic resource. However, these transformations do not occur overnight. Whereas academics and institutions may be able to change their viewpoints quickly, communities may be reticent to accept or unable to contribute to the new economic framework.

In the United States, the postindustrial context paved the way for the implementation of large industrial corridors and territorial projects of enhancement linking industrial heritage with tourism, such as national heritage areas and regional parks: Augusta Canal, Rivers of Steel, Blackstone, or Keweenaw National Historical Park (Liesch 2011). In contrast, a positivist conceptualization of industrial heritage has accompanied Spanish academics' and institutions' straightforward embracing of it. Heritage is thus the monumental: the factory, the train, and the mining pit, but not the territory as a whole along with natural areas and local communities.

\section{Heritage and Place Identity: The Challenge of Identification}

It is a challenge for decaying industrial areas to avoid homogenization and becoming "junkspace" or "nonplaces" (Koolhaas 2002; Augé 2008). The productivist paradigm has eroded the idea of "place" and replaced it with "space" through 
constant dissolution of the constitutive elements of territorial identity and complexity (Casey 1997; Choay 2007). Notwithstanding their potential value as "lieux de mémoire" (Nora 1989), the emphasis on sites-as-monuments is also a modern inheritance. Consequently, the emphasis may hinder the regeneration of place identities because the conceptualization of heritage as "space" rather than "place" obscures the production of heritage at wider territorial and intangible levels of the social sphere (Atkinson 2007). Instead, approaches that underscore landscape or wider territorial views generally may facilitate integration and generation of place identity. This is so because heritage, when considered form a naive and objectoriented point of view, is intrinsically contentious (García Canclini 1999). It can disinherit or exclude those who are not embraced within the meaning ascribed to it. In other words, heritage is a double-edged sword: It may foster allegiance and a sense of purpose as well as rejection (Harvey 2008, 32).

The current process of repersonalizing the economy and physical space revolves around people's generation of new meanings and new identities (Bonomi and Rullani 2005). Accordingly, "streets, factories, and monuments are being enveloped in a network of meanings that assign names and meanings to things. . . . Places are no longer givens, but are ... produced by the people who inhabit them, if they give meaning to their co-habitation, establishing a hierarchy of distances between what is-physically or culturally-close and, on the other hand, what is, and remains, distant, faraway" (Rullani 2009, 243). Meaning gives value to heritage, either cultural or financial (Graham and Howard 2008). Thus, what is at stake is not so much "preservation" as the social and material construction of a new place identity that may engage and carry the community with it in a new process of growth with novel foundations. Industrial heritage thus helps marking place, also bounding people in notions of belonging, ownership, and, consequently, identity (Kuusisto 1999).

In Spain, many stakeholders thought that the coupling of cultural tourism with industrial heritage would create a solid pillar for development that would take other economic sectors with it. By inserting new cultural symbols that would resonate with local sense of heritage and identity, both aspects of industrial heritage would provide the territorializing acts that the community needed to generate a new place identity: memory and identity, economic sustainability . . . and hope. Therefore, territorial value to capture rent, and place identity to underpin social cohesion and provide territorial value, must go hand in hand (Magnaghi 2005). However, with few exceptions, and despite significant financial, academic, and institutional efforts, there has been a failure in Spain to bring industrial heritage physically and emotionally close to wider sectors of the population and to use it with success in processes of economic regeneration.

\section{Spain's Industrial Heritage}

Generally, awareness of industrial remains came later in Spain than in other European countries with long-standing industrial traditions. The process of deindustrialization that dated from the 1980 os led to the closure of firms, mass layoffs, 
and abandonment of industrial sites and areas. Initially, the compelling economic and labor problem obscured the issue of derelict industrial sites. Knocking down old factory buildings and holding back the freed land for speculative purposes seemed appropriate. The potential town-planning problems and opportunities associated with industrial remains were not perceived. However, when the effects of the industrial and urban crisis became manifest, and when policies for reindustrialization showed their limitations for the creation of new industries in formerly industrialized places, thoughts turned back to industrial heritage. What was to be done with it? How were the environmental and town-planning impacts of withering factories, workshops, mines, and railways to be dealt with?

A solid strand of opinion and thinking has subsequently arisen which is sensitive to both industrial remains and the problems they pose, as well as to the need to seek suitable solutions. This preoccupation took concrete form in the 1990 s as proposals for interventions based on the idea of protecting and preserving abandoned industrial structures, buildings, and areas rather than destroying or eliminating traces of former industry. Various arguments from grassroots platforms and from some academic quarters justified this about-face in the way of handling industrial remains. These actors appealed to the cultural, identity-building, and scientific value of the remains-and to their potential role as tourist attractions (Corner and Harvey 1991; Feliú Torras 1998).

The Spanish approach to the issue changed due to the increasing interest in industrial heritage by such international institutions as the International Council on Monuments and Sites, the U.N. Educational, Scientific and Cultural Organization, and The International Committee for the Conservation of the Industrial Heritage, and to the influence of other European countries, such as the United Kingdom, Belgium, France, and Germany, that had already experienced the transition to postproductivism. In particular, Great Britain was the birthplace of a popular passion for industrial remains, where grassroots activists and academics from different disciplines gathered around what came to be known as "industrial archaeology." The discipline had a significant popular appeal and its own founding myths, such as the demolition of the Euston Arch or the creation of the Ironbridge Gorge Museum in the 1960s. Definitions of the new discipline differed: Andrea Carandini defined it as a "contemporary archaeology" (1984); Kenneth Hudson considered it the discovery, cataloging, and study of physical remnants, transportation and communications infrastructures, and the documentation of industrial history (1963); for Robert Buchanan it was a practical and theoretical field of study seeking to protect industrial monuments and concentrating on the investigation of industrial remnants in the context of social and technical history (1974).

However, neither in Spain nor in Europe did industrial archaeology provide a satisfactory solution for the problems that industrial remains posed (Cossons 1975; Borsi 1978; Pinard 1985). Apart from lacking an applied or purposeful dimension, it focused too much on sites and objects, leaving aside the spatial dimension. This fact partially explains the general lack of a territorial emphasis in industrial 
enhancement projects in Spain until recent times. Stakeholders regarded industrial remains as monuments-single, isolated elements of note-rather than as elements that could be incorporated into policies for regional and urban development.

Also, the prevalence of architects, engineers, and, to a lesser extent, historians and archaeologists in the discipline has led research to focus on the restoration of buildings, the study of objects, and the elaboration of histories, with an emphasis on technical matters (Reyes Téllez 2004). Studies from the social sciences-especially anthropology and sociology, but also geography-are almost completely lacking, and so, therefore, is understanding of matters related to place identity, involvement of local people, and attachment to industrial remains or the relationship between industrial sites and their surrounding territory. Thus we are not in a position to assess the value that the Spanish people give to the enhancement of industrial heritage. Much more effort has been devoted to analyzing the potential of industrial heritage as an economic resource than to the actual development of methods and theories for its study (Castro Morales 2001). A great deal of research is needed in this direction to provide case-study analyses of specific contexts and thus to shed light on the topic.

However, we can affirm that academic and institutional interest in the topic has skyrocketed since the 1990s. National and regional legislation increasingly acknowledges the relevance of industrial heritage (Hidalgo Geralt 2010). Also, an extensive literature on the topic appeared during the 1990s, and the theoretical debate has gained geographical depth and breadth since the VII International Congress for Conservation of Industrial Heritage, held in Madrid in 1992. However, the response of Spanish scholars arrived late and largely imported foreign theories and methods.

Eusebi Casanelles y Rahola was the first to point to the need to take into account the territorial dimension of Spain's industrial heritage (1998). Accordingly, from his position as director of the Catalonia Science and Technology Museum, created in 1982, he fostered a territorial conception of the museum as a network of sites and interpretative centers that would tell the story of the Catalan industrialization process (Casanelles y Rahola 2004). Horacio Capel and José Ortega Valcárcel maintained that derelict industrial buildings may offer architectural values and should therefore be preserved or reutilized as part of wide-ranging operations aimed at urban regeneration (Capel 1996; Ortega Valcárcel 1998). Barcelona has been a leading city in this regard, in a process not devoid of contentious issues related to gentrification and commodification of heritage (Tironi 2009).

Some geographers expressed their interest in the town-planning opportunities offered by derelict industrial sites in large cities like Madrid (Pardo Abad and Olivera 1992). Some delved deeply into the relationship between industrial heritage and local development (Rodríguez Gutiérrez 1992; Troitiño Vinuesa 1998), or between cultural heritage and land-use planning (Bielza de Ory and Miguel González 1997). Geographers also showed interest in the role that industrial heritage might play in reactivating areas in crisis (Benito del Pozo 1997). 


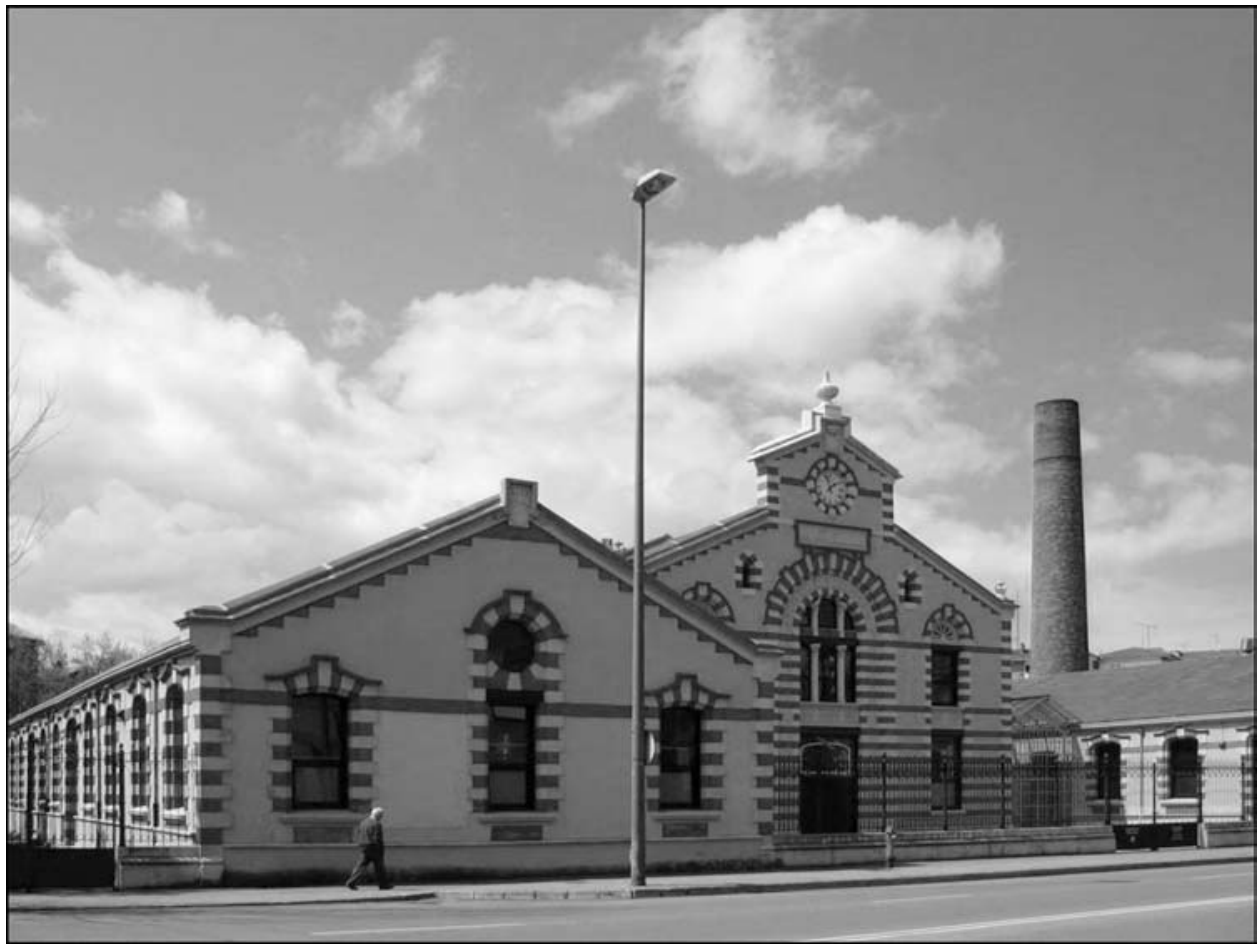

FIg. 1-La Curtidora Enterprise Center in Avilés, Asturias, northern Spain. (Photograph by Paz Benito, April 2004)

\section{European and National Programs in Spain}

At present, actions related to industrial heritage are widespread in Spain. With the support of various national, regional, and European institutions, many middlesized cities, rural areas, and mining regions have created museums and interpretative centers (INCUNA 2002).

The European Union's sensitivity toward the issue became manifest in a series of projects to protect and enhance industrial heritage from 1984 onward. In Spain, the most influential were the National Community Interest Program, the Resider I for steel-producing areas, and the Agenda 2000 that brought together the previous European Raphaël, Kaleidoscope, and Ariane cultural programs (Benito del Pozo 2005). Those programs had varying degrees of impact and scope, but overall they raised awareness among Spanish institutions and academics of the significance of industrial heritage. For example, they allowed for the implementation of projects like the Mining Museum of El Entrego, the rehabilitation of the Industrial Complex of Valnalón, the Cristasa Enterprise Center, and the La Curtidora Enterprise Center, all located in mining, iron- and steel-producing areas in crisis in northern Spain (Figure 1).

The most relevant Spanish initiative was the ambitious National Industrial Heritage Plan, started in 2000. The plan acknowledged the value of industrial 
remains as part of the nation's history. Nonetheless, the main objective was to use industrial heritage as a resource for economic development and community integration in regions where traces of the collapsed industrial economy remained, whether material or immaterial in form (Hidalgo Geralt 2010; Pardo Abad 2010). The plan was implemented in phases. First, the most-valuable properties were selected through a general inventory. Second, the selected elements were catalogued. Third, actions were defined for protecting the properties picked out; and fourth, a master plan was drafted for interventions to restore and make use of them. As of February 2012, forty-nine elements scattered across Spain had been selected. Although in theory considerable effort has been made, in practice the plan has not brought the hoped-for territorial development.

Within Spain, the regional governments and autonomous communities enjoy a high degree of self-governance in a range of areas, including the cultural realm. Thus the management of industrial heritage relies primarily on regional governments. Spanish industrialization started in Catalonia in the late seventeenth century, followed by the Basque Country, Valencia, and other northern regions such as Asturias and Galicia. In those areas, industry has always related to narratives of national identity to some extent. Also, popular attachment to industrial remains is higher in those regions than elsewhere in Spain, as shown by the appearance of the Basque Association of Industrial Heritage and Public Works, Buxa (the Galician Industrial Patrimony Association), the Industry, Culture and Nature association (Asturias), and other active industrial heritage groups since the 1990s. Also, regions have been in charge of creating most of the industrial heritage catalogs, with varying degrees of success.

What is important about the actions described is not so much their institutional and political dimension understanding the extent to which they are able to generate prosperity and well-being in places from which industry has disappeared. The hoped-for positive effects have been limited and feeble in intensity so far. Many cities and regions are only at the phase of selective and tentative intervention; that is, at the stage dominated by efforts to rehabilitate catalogued buildings and to reuse derelict sites for alternative urban developments that have yet to trigger any appreciable synergies of growth.

As an exception, some pioneering areas can point to consolidated experiences that have been successful and are an example of good practice in recovering industrial remains for alternative purposes. Among these is the use made of former mines, old ironworks and steelworks, or textile mills for different purposes throughout Spain, whether as museums, multifunctional centers, tourist attractions, or housing. Most are probably stories of failure. This is the case of the Electromecánica of Córdoba, a major industrial heritage complex whose destruction has been ongoing in the last decade despite opposition from academics and civil platforms (Cano Sanchiz 2008).

But some are also stories of success: Examples include the conversions into heritage sites of the mines of La Sierra de la Unión (Murcia), Hiendelancina (Cas- 
tilla-La Mancha), and Linares and Riotinto (Andalusia), the last of which welcomed 74,000 visitors in 2007, or the creation of the Fluvial Park of the Colònies del Llobregat (Catalonia) and the industrial and mining museums of Puertollano (Castilla-La Mancha) and Sabero (Castilla y León). Thus, when people and institutions become involved and collaborate in rehabilitating industrial heritage as a resource, the area becomes more dynamic and generates more opportunities for economic development (Sabaté and Benito del Pozo 2010).

\section{Place Identity and Territory: \\ From Museums and Monuments to Cultural Landscapes}

When industries and mines close down, the affected areas and urban centers start looking for economic alternatives and new models of social identification to sustain the cohesion of local communities. Normally, in the transition to a servicebased economy, tourism is regarded as the main, if not the only, substitute for industrial activity. Although some areas may be able to resort to other touristic resources-landscapes, gastronomy, architecture, or history, for example-most paradoxically find that the industrial remains are their only resources to be converted into heritage elements. Normally, local governments and elites take the lead role in launching the process of transformation, with the support of different regional, national, and European institutions (Ruiz Ballesteros 1999; Dicks 2000). They set out processes of what Rullani calls "place-creation" (2009). These processes are also in David Robertson's work on a mining community (2006).

The construction of places entails a renegotiation of meanings related to industrial heritage, both at the material level and the symbolic one. It is thus necessary to decide what to do with the material remains and how to set out the new identity around which the community should gather (DeLyser 1999). However, in many cases the implementation and academic analysis of these processes disregard the role of local people in negotiating the process of transformation, whether through rejection, support, or passivity. Also, in most cases institutions carry out the projects without any assessment by academics or professionals who are knowledgeable about industrial heritage matters. This fact leads to an old-fashioned and object-oriented approach to the enhancement of heritage that emphasizes the building and the museum while disregarding the landscape.

Leaving aside the backwardness of some institutional and academic approaches, assessments of the degree to which local people become involved and support these practices of enhancement are also necessary. The aforementioned lack of critical case-study analysis coming from the social sciences in Spain leaves us devoid of tools to review this matter in depth.

Nonetheless, the results of investigations such as that by Esteban Ruiz Ballesteros and Macarena Hernández Ramírez, which were published in 2007, resonate with our own experience and the research carried out by Pablo Alonso in the former industrial village of Val de San Lorenzo. Ruiz and Hernandez emphasize how the role of local communities in the transition from industry to a tourism economy 
has been overlooked and underestimated. They note how, despite the strong effort made by local governments, the support received from academia and public institutions, and the overall good performance of Andalusia in the tourism economy, the transformation of the four villages under study into heritage sites largely failed due to local people's passivity and lack of interest. Furthermore, the authors note how local industrial heritage associations were unable to energize local residents and were actually elitist organizations, functioning more as lobbies influencing local governments than as representatives of local popular opinion (Ruiz Ballesteros and Hernandez Ramirez 2007). The motto stating that industrial heritage is a heritage of the people for the people may apply in Great Britain, but it does not in Spain, where industrial heritage is being activated without the people and for the tourism sector. Overall, it is not broadly valued, with what are probably the sole regional exceptions of Catalonia and Basque Country, where, in any case, industrial heritage is far from being broadly popular or socially relevant (Âlvarez Areces 1992; Sobrino 1996; Cañizares Ruiz 2002).

Three main factors influence this rejection of industrial heritage. First, industrial heritage brings back negative memories of class and power struggles, poor working conditions, and the always contentious negotiations among the labor force, institutions, and entrepreneurs when the end of industrial activities is imminent. Second, a rooted romantic idea in Spain perceives industry as a modern corruption of the pristine previous vernacular world of peace and harmony with nature. People consider industries ugly. Contrary to David Harvey's case study in Great Britain (2008), where the local community did not feel the need to go back to a supposedly better past, fear of industrial modernity continues to exist in Spain. Thus it should come as no surprise that many former industrial areas, in their efforts to build a new place identity, simply dismiss and put aside their industrial past and hark back to a preindustrial past, as happened in Villanueva, a coalmining area near Seville (Ruiz Ballesteros and Hernández Ramírez 2007, 685). Third, heritage is always related with Otherness (Viejo-Rose 2011). It generates Otherness because it is always a matter of property, whether symbolic or material: This is my heritage and thus not yours. But Otherness is also necessary for it to be considered, and especially to be emotionally felt by people, as heritage. And industrial heritage is still felt mostly as part of the everyday, far from being part of another reality.

In sum, the lack of local interest in industrial heritage undermines both the creation of a new place identity and the possibility of an alternative economic development based on tourism. Another feasible possibility is that the social groups interested in the enhancement of industrial remains are able to create a network of meanings that conveys a simulacrum identity linked to flows of tourism but completely detached from the local community's sense of place, as we will see in Val de San Lorenzo.

These aspects and the absence of case-study analysis to sound the alarm of problems associated with industrial heritage enhancement are not trivial issues at 
all. Huge sums of money have been, and are being, channeled toward industrial heritage without any certainty about what results will be achieved, in relation to the building of place identities, the enhancement of communities' cohesion and the economic return on the investments. As Ruiz Ballesteros and Hernández Ramírez put it, "If there is no community or mining identity, if features and cultural elements related to mining are not activated symbolically, it is highly unlikely that they will be developed successfully as a tourist resource: in other words, it will be difficult to create consistent mining heritage tourism" (2007, 681). Spanish academics should then stop praising the beauty and supposed fine values of industrial heritage preservation in a positivist stance and also stop importing foreign models that do not apply to the Spanish context; they should start empirically analyzing what happens in specific contexts with industrial heritage. Who is interested in enhancing industrial heritage, and why? Should we be investing huge amounts of money in it? How is industrial heritage connected to or marginalized from identity-building discourses? Can understanding of industrial heritage and its associated place identities increase local residents' involvement and support?

\section{Place Identity and Territory in the Museum: Val de San Lorenzo, León}

Val de San Lorenzo is a small village in a peripheral area of northern Spain. It has had a tradition of textile fabrication since medieval times and started the transition to industrialism quite late. Artisans began to import secondhand and thirdhand machinery from Catalonia (which in turn lagged behind the British textile industry) at the end of the nineteenth century (Alonso González 2007b). Curiously enough, some of the looms dating from the 1850 are still in use. The industrial complex of the village comprised textile and dye factories, first hydraulic, then electric after the 1930s. Most strikingly, due to the influence of local migrants who returned from South America and to the spread of socialism and Marxism at the time in Spain, a communal productive trend arose alongside the birth of liberal and individualistic factories that followed the models of Catalonia and Great Britain. Consequently, local people created an association and built two communal factories that survived the Civil War and the fascist dictatorship of Francisco Franco (1936-1975), only to collapse in 2000. After an industrial apogee during the 1960 s and 1970s, both the liberal and communal factories started a process of decay that culminated during the 2000 (Alonso González 2007a).

The local government and upper-class liberal entrepreneurs began to look for alternative sources of economic development and chose cultural tourism as a potential solution. The main initiatives were the creation of the Batán-Museum in 2000 and the conversion of the communal factory La Comunal into an interpretative center for the textile industry in 2006. European Structural Funds financed the projects with the support of provincial and regional governments. Without seeking any further professional or expert counseling, the governments commissioned an architect for the buildings. The museums tell the story of the "progress" 


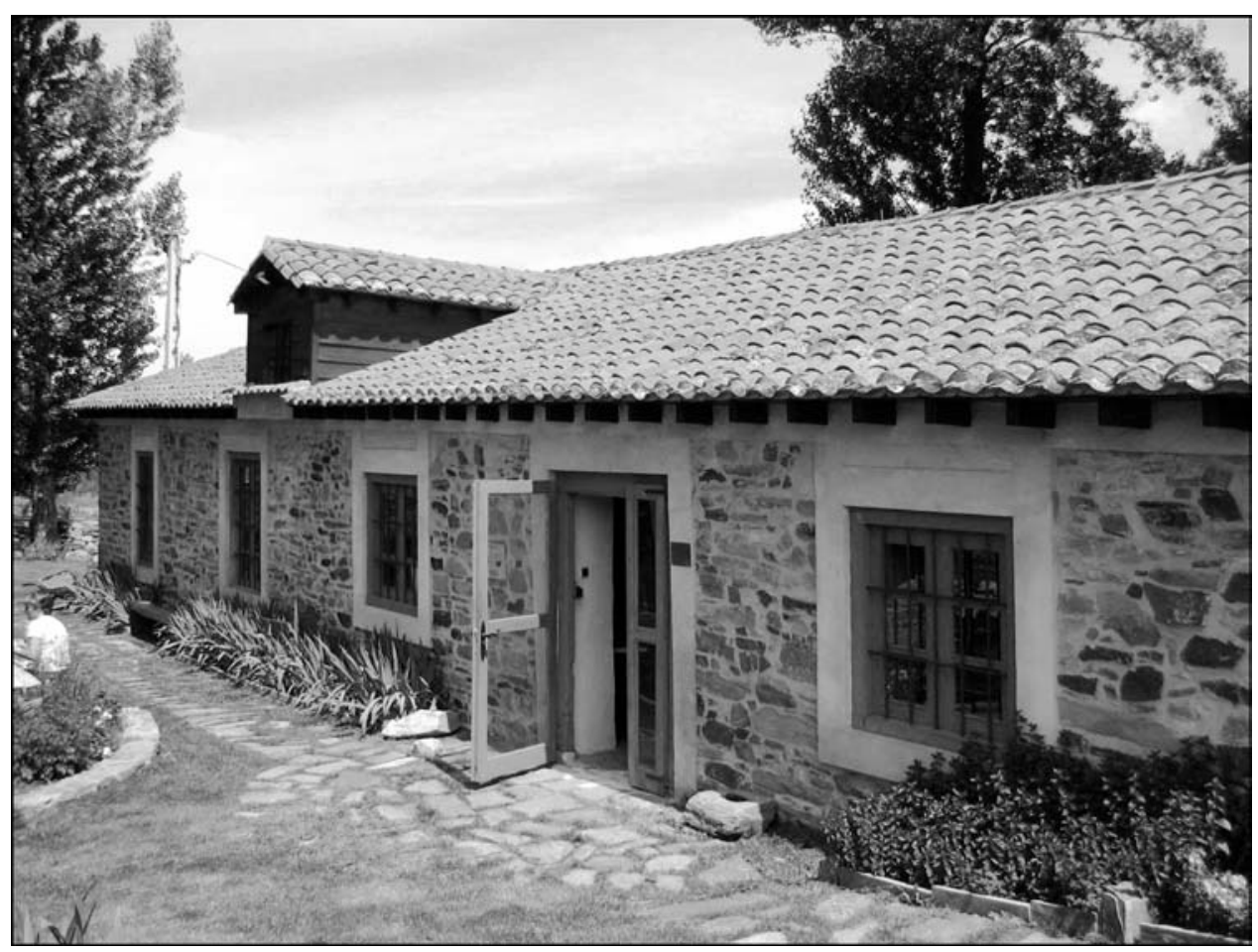

FIG. 2-Batán-Museum, an old hydraulic factory converted into an interpretative center in Val de San Lorenzo, León, Spain. (Photograph by Paz Benito, July 2004)

of the village, going from the preindustrial times in the hydraulic factory in the Batán-Museum to the industrial times in La Comunal. In parallel, the upper-class former liberal textile entrepreneurs opened restaurants and hotels in the new touristic economy, within which most local residents cannot participate as stakeholders (Figure 2).

La Comunal interpretative center deploys a narrative thread that goes from a set of wooden tools and looms to a modern iron tool. Paradoxically, the center is housed in the (embellished and transformed into a heritage element) communal factory (Figures 3 and 4 ). No mention is made of the dialectical relationship between La Comunal and the liberal textile producers. The narrative hides contentious issues and recounts a story of progress, thus creating new meanings that underpin the new place identity being created in the village based on tradition, gastronomy, and a pristine textile past (Alonso González 2009). There are no references to the landscapes of wool production or even to the crumbling factories and craft workshops around both museums, which have been left to their fate. The museums encapsulate the territory, working as the backbone of a new economy that exclusively needs a symbolic identification for touristic purposes to provide value to the village. Therefore, instead of the spatialization of history (McDowell 2008), what we find is a historicization of place. 


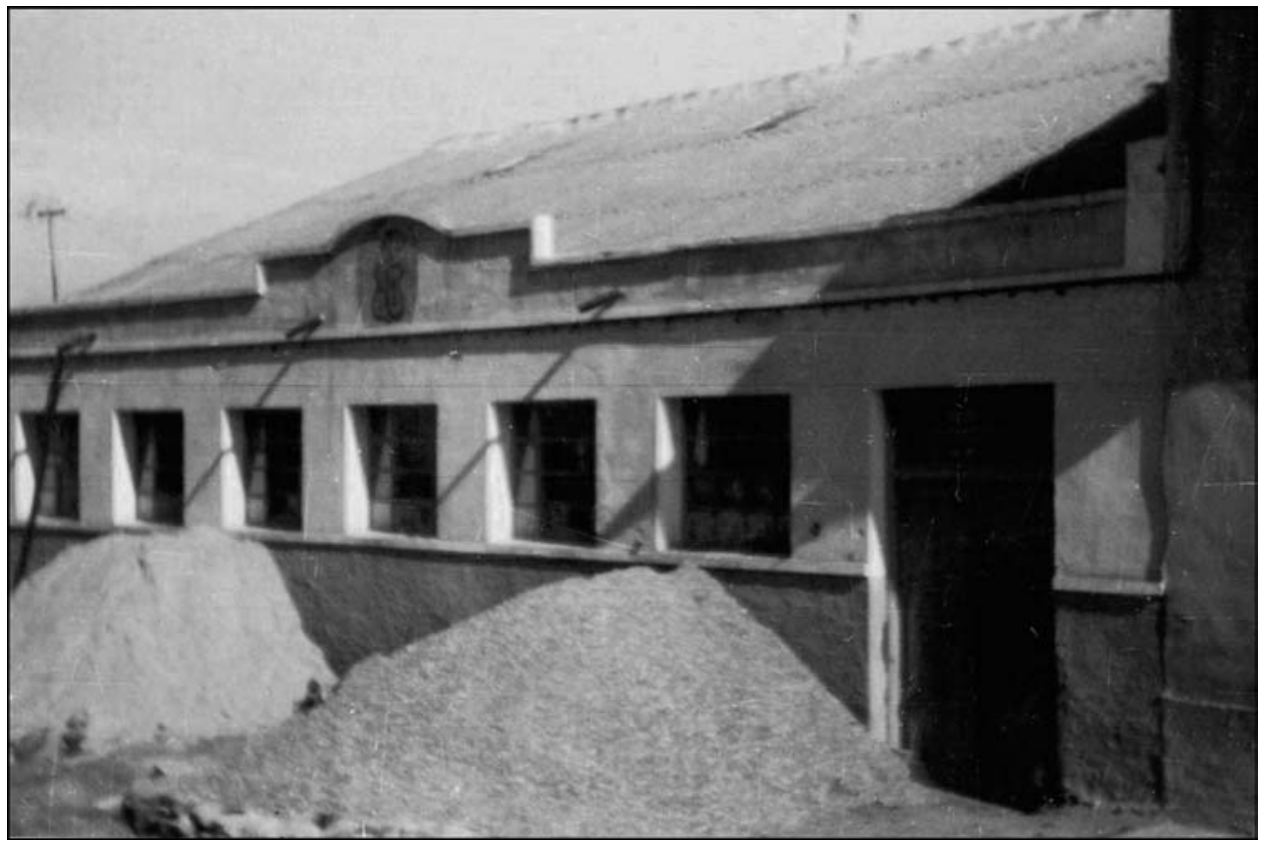

FIG. 3-La Comunal, a communal factory in Val de San Lorenzo, León, Spain, as it looked before it was converted into an interpretative center for the textile industry. (Photograph by Pablo Alonso, May 1989)

Ethnographic research showed an overall ambivalence of the populace regarding industrial heritage. Apart from other instruments and machines, most families had a wooden loom and a mechanical loom at home; burning the former and selling the latter as scrap iron were common. Some families preserved a loom in their living room or kitchen, as the heart of the family's home. Assessing the degree of local attachment to the industrial remains is thus difficult. Overall, though, the general sentiment is passivity and disinterest. However, ethnography showed that local residents' attitude toward the museums and the new touristic economy was clearly that of rejection. Most of the former communal producers had never stepped into the refurbished buildings and considered the "museum affair" as foreign and unrelated to them (Alonso González 2009).

We presume that the picture described in Val de San Lorenzo could easily be extrapolated to many museums and rehabilitation projects throughout Spain. The links between industrial heritage and identity are always ambivalent and intrinsically intermingled with issues of power and class, thus being troublesome elements to use as efficient tools in the production of new places for touristic purposes. This will be so even if institutions and socioeconomic elites are determined to fund and support these kinds of industrial heritage projects. This situation has apparent implications for the touristic economy. In Val de San Lorenzo, the lack of popular involvement and the absence of a more open approach to industrial heritage, one that would move beyond the walls of the museum, reduce the scope of the 


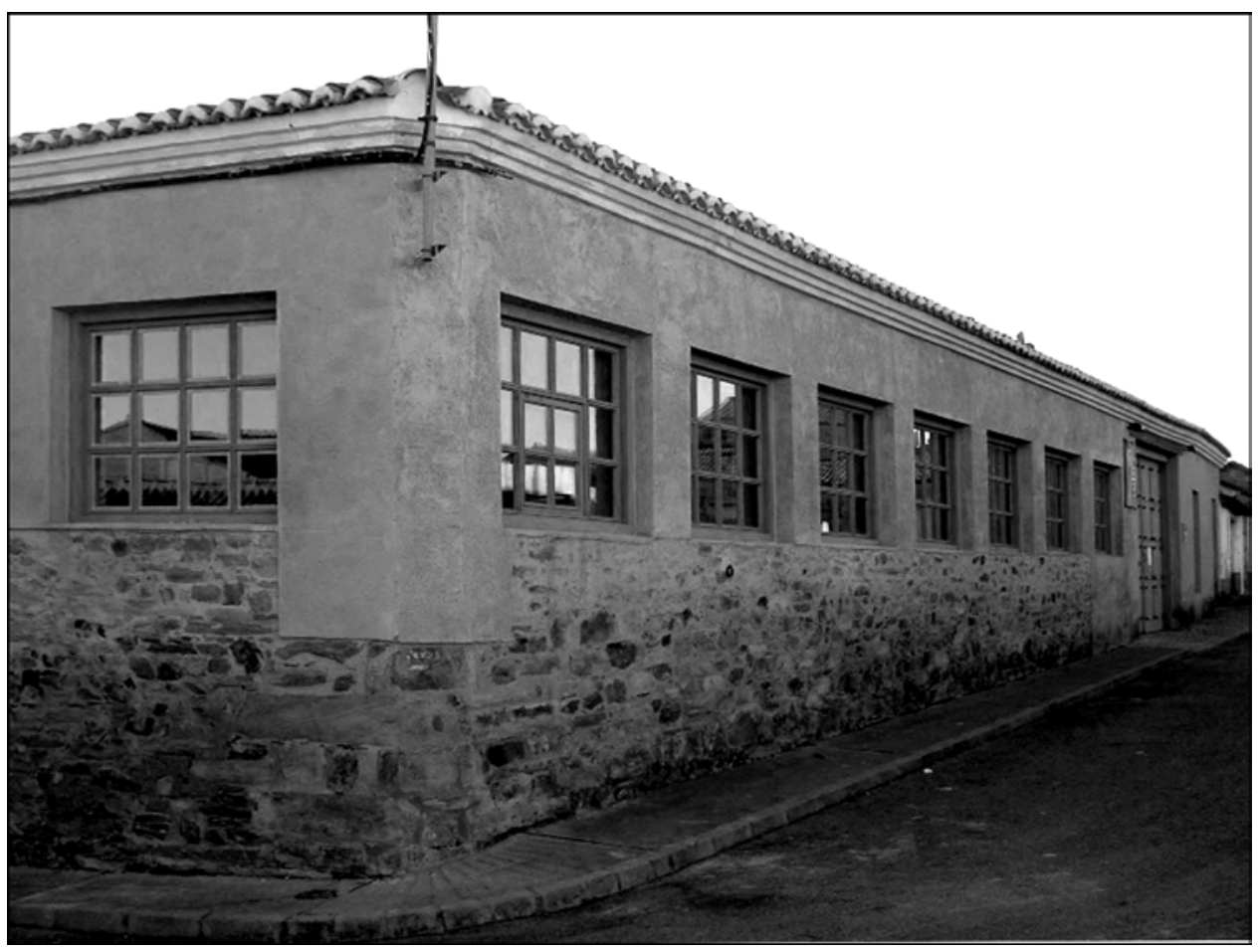

FIG. 4-The same former communual factory shown in Figure 3 after its conversion into an interpretive center. In hope of attracting tourists, the concrete was removed from the walls so the stones are now visible. Fresh paint and a new roof, windows, doors, and interior decor have rendered the building more like traditional-vernacular architectural standards in the area and less "industrial." (Photograph by Pablo Alonso, November 2008)

touristic enterprise and ultimately undermines it. In fact, tourism is not thriving in the village.

\section{Place Identity as Cultural Landscape: \\ The Colònies del Llobregat Fluvial Park}

Lately, a new trend in the preservation and enhancement of industrial remains has emerged that connects them to territorial projects of place production as "cultural landscapes." However, scholars who use this approach, which overcomes the idea that place identity and heritage are limited to monuments and museums, are still in the minority. The paradigm shift emerged in relation to the influence of the belated arrival to Spanish social theory of the social constructivist turn in geography and other social sciences, which has reached spatial planning and landscape architecture as well. Postempiricist (Schein 2006), Deleuzian (Bonta and Protevi 2004), or nonrepresentational (Thrift 2008) approaches are not still widespread among Spanish geographical or spatial planning thinkers. Thus academics conceive landscape subjectively as a social construction, an extension of cultural heritage and its interpretation (Nogué 2007). Accordingly, landscapes reflect the organization of land and are socially constructed within a framework of complex 
and changing relationships among classes, sexes, races, and power. Industrial landscapes are considered to be areas marked with powerful identity signs, so they are well suited for involvement in territorial projects of heritage enhancement, such as cultural parks (Europe) or heritage areas (United States).

The work of the architect Joaquín Sabaté are paramount in this regard. He has developed a pragmatic approach to territorial enhancement projects that resonates with theoretical and methodological approaches which are widespread in the United States (Sabaté and Frenchman 2001). For him, a cultural landscape is "geographical ground associated with an event, an activity, or a historical character that contains aesthetic and cultural values" (Sabaté 2005; translated by Pablo Alonso).

In turn, a cultural park is a tool to project and manage, to recognize and enhance, a specific cultural landscape, whose aim is not only to preserve heritage or to promote education but also to favor local economic development (Sabaté 2009). These approaches to the territory favor an open conception of development and heritage, in which the two concepts are not opposed but intermingle to generate socioeconomic synergies. In principle, these kinds of projects seem to be democratic and inclusive, because they encourage participation and work as dynamic "umbrellas" under which different social initiatives can thrive. Again, however, we lack ethnographic accounts to assess the empirical consequences of these projects in relation to economic development and place-identity building.

The most developed project set out by Sabaté, in collaboration with Pere Vall, was the Colònies del Llobregat Fluvial Park in Catalonia. This is a historic industrial valley of the Llobregat River, which ends near Barcelona. During the nineteenth century factories sprawled around its meanders, profiting from hydraulic power, and industrial villages called "colónies," which resembled the first English garden cities, flourished around them (Vall 2008). This gave rise to a half-agricultural, half-industrial landscape, as handworkers in the factories would also work the land. The advent of electricity during the twentieth century rendered the water-powered factories dispensable, so the whole valley and its colonies entered a period of decline that continues to this day.

In 2003 the provincial government of Barcelona and the Polytechnic University of Catalonia, with the support of some grassroots groups in the valley, created the Llobregat River Park Consortium. The aim was to boost tourism by creating a new place identity based on the promotion and preservation of its cultural and natural heritage, with industrial heritage as the backbone of the project. The master plan was developed between 2005 and 2007 to address territorial imbalances along with urban and industrial preservation. The planning strategy set out works at a level intermediate between the urban scale and the regional scale in order to facilitate a comprehensive understanding of the identity of the valley while enabling planners to work on individual colonies and sites (Vall 2008).

The plan foresees a balance between public and private participation, the former channeling funds toward preservation and the latter, toward investment. Most 
industrial spaces are being converted into residential areas or are intended for tertiary uses. Notwithstanding, the project does not undermine the status of industrial monuments, which become part of the broader framework of the park as nodes of meanings within a complex network where place identity and economy establish a synergistic relationship. For better or for worse, when the project starts to bear fruit it will open a way forward in the Spanish approach to industrial remains and their connection to place identities and territories.

\section{From Industrial Monuments to Industrial Landscapes}

As the different initiatives reviewed above have shown, academic and institutional spheres recognize industrial heritage as part of the broad cultural inheritance of Spain, as a resource with huge possibilities for economic reactivation, architectural rehabilitation, museum creation, and urban and spatial planning. Derelict industrial sites are more and more the source of projects that combine business with operations aimed at the-always contentious-regeneration of rundown districts. However, in many cases the emphasis placed on the monumental and on the economic potential of industrial heritage, to the detriment of its dialectical relationship with place identity and memory, has led to passivity and even rejection of projects among residents of local communities. In turn, this rather unenthusiastic attitude of the local populace undermines the primary aims of economic regeneration and development in a vicious circle in which millions of euros in investments are at risk. This rejection cannot be linked solely to symbolic factors; it is intrinsically related to issues of class and power relationships that cannot be overlooked in enhancement projects. The lack of research carried out to date in this direction makes it difficult to evaluate the extent to which these symbolic and material struggles are going on in industrial heritage enhancement projects.

Projects that focus on the territorial value of industrial remains might offer a potential way out of the vicious circle. They provide a more open approach to place identity and partially overcome contentious issues by encouraging local participation and by working as an umbrella under which a wide array of socioeconomic projects can thrive. This shift toward an approach based on landscapes rather than on museums or monuments is developing gradually and with regional imbalances. The idea is to go beyond the industrial item - the building-and consider the process of industrialization as a whole. This implies paying attention to all of the factors that made possible an industry and the organization of space in relation to it. These run the gamut from the existence of raw materials and sources of energy, through systems of transportation and for distribution of goods, to questions related to the location and construction of factories. In bygone days a cycle of production involving a populace and its forms of settlement (villages, towns, and cities) created a unique landscape, one that bore a rich load of heritage and culture, whether on the coast or inland, whether in a mountain valleys, on a plateau, or in a delta.

Many of these landscapes are in peril because their cultural value is not recognized. Therefore, actions and projects affect their elements in isolation, breaking 
the thread that gives unity to the whole and explains it. It is neither reasonable nor sustainable to act upon isolated elements, however valuable they may be, and ignore the surrounding landscape. This is the greatest challenge on the horizon for industrial heritage in Spain.

\section{REFERENCES}

Alonso González, P. 2007a. La arqueología industrial en León: Reflexiones a partir de la investigación en el Val de San Lorenzo. Estudios Humanísticos: Historia, No. 6: 295-315.

. 2007b. Arqueología industrial en el Val de San Lorenzo. León, Spain: Centro de Iniciativas Turísticas de Astorga.

- 2009. Etnoarqueología y gestión del patrimonio cultural: Maragatería y Val de San Lorenzo. León, Spain: Universidad de Léon.

Álvarez Areces, M. A. 1992. Recuperación y uso del patrimonio industrial: Problemas y experiencias en curso (el caso de Asturias). Ábaco: Revista de Cultura y Ciencias Sociales, No. 1: 57-66.

Atkinson, D. 2007. Kitsch Geographies and the Everyday Spaces of Social Memory. Environment and Planning A 39 (3): 521-540.

Augé, M. 2008. Non-Places: Introduction to an Anthropology of Supermodernity. London: Verso.

Benito del Pozo, P. 1997. Dinamización del territorio y patrimonio industrial. Polígonos: Revista de Geografía, No. 7: 123-132.

- 2005. Pautas actuales de la relación entre industria y ciudad. Ería: Revista Cuatrimestral de Geografía, No. 66: 57-70.

Bielza de Ory, V., and R. de Miguel González. 1997. El patrimonio cultural, componente de la ordenación del territorio. Revista Aragonesa de Administración Pública, No. 10: 185-208.

Bonomi, A., and E. Rullani. 2005. Il capitalismo personale: Vite al lavoro. Turin, Italy: Einaudi.

Bonta, M., and J. Protevi. 2004. Deleuze and Geophilosophy: A Guide and Glossary. Edinburgh: Edinburgh University Press.

Borsi, F. 1978. Introduzione alla archeologia industriale. Rome: Officina Edizioni.

Buchanan, R. A. 1974. Industrial Archaeology in Britain. London: Allen Lane.

Cañizares Ruiz, M. del C. 2002. La infravaloración del patrimonio industrial urbano: El Apartadero Calatrava en Puertollano (Ciudad Real). In Turismo y transformaciones urbanas en el siglo XXI, edited by F. Fernández, P. Pumares, and A. Asensio, 493-504. Almería, Spain: Universidad de Almería.

Cano Sánchiz, J. M. 2008. Arqueología industrial en Córdoba: La sociedad española de construcciones electromecánicas (1917-1930). Anales de Arqueología Cordobesa, No. 19: 361-386.

Capel, H. 1996. La rehabilitación y el uso del patrimonio histórico industrial. Documents d'Anàlisi Geogràfica, No. 29: 19-50. [http://ddd.uab.es/pub/dag/o2121573n29p19.pdf].

Carandini, A. 1984. Arqueología y cultura material. Barcelona: Mitre.

Casanelles y Rahola, E. 1998. Recuperación y uso del patrimonio industrial. Ábaco: Revista de Cultura $y$ Ciencias Sociales, No. 19: 11-18.

- 2004. El sistema del Museu de la Ciència i de la Tècnica de Catalunya. Revista de 10ocias@UNED, No. 7: 147-149.

Casey, E. S. 1997. The Fate of Place: A Philosophical History. Berkeley: University of California Press.

Castro Morales, F. 2001. Memoria, ocio y cultura: Nuevos usos en España para el patrimonio industrial. In Preservación de la arquitectura industrial en Iberoamérica y España, 204-212. Seville: Instituto Andaluz de Patrimonio Histórico.

Choay, F. 2007. Alegoria del patrimonio. Barcelona: Gustavo Gili.

Corner, J., and S. Harvey, eds. 1991. Enterprise and Heritage: Crosscurrents of National Culture. New York: Routledge.

Cossons, N. 1975. The BP Book of Industrial Archaeology. North Pomfret, Vt.: David \& Charles.

DeLyser, D. 1999. Authenticity on the Ground: Engaging the Past in a California Ghost Town. Annals of the Association of American Geographers 89 (4): 602-632.

Dicks, B. 2000. Heritage, Place and Community. Cardiff: University of Wales Press.

Feliú Torras, A. 1998. El patrimonio industrial, localizaciones, regeneraciones: Una nueva geografía. Ábaco: Revista de Cultura y Ciencias Sociales, No. 19: 71-80.

Fumagalli, A. 2007. Bioeconomia e capitalismo cognitivo: Verso un nuovo paradigma di accumulazione. Rome: Carocci. 
García Canclini, N. 1999. Los usos sociales del patrimonio cultural. In Patrimonio etnológico: Nuevas perspectivas de estudio, edited by E. Aguilar Criado, 16-33. Seville: Consejo de Cultura, Junta de Andalucía. [www.antropologiasocial.org/contenidos/tutoriales/patrimonio/textos/canclini.pdf].

Graham, B., and P. Howard. 2008. Introduction: Heritage and Identity. In The Ashgate Research Companion to Heritage and Identity, edited by B. Graham and P. Howard, 1-18. Aldershot, U.K.: Ashgate.

Gunder, M. 2010. Planning as the Ideology of (Neoliberal) Space. Planning Theory 9 (4): 298-314.

Harvey, D. 2002. The Art of Rent: Globalization, Monopoly and the Commodification of Culture. Socialist Register 38: 93-110.

- 2008. The History of Heritage. In The Ashgate Research Companion to Heritage and Identity, edited by B. Graham and P. Howard, 19-36. Aldershot, U.K.: Ashgate.

Hidalgo Geralt, C. 2010. El patrimonio minero-industrial y ferroviario: Nuevos recursos para nuevos turismos. Ph.D. diss., Universidad Autónoma de Madrid.

Hudson, K. 1963. Industrial Archaeology: An Introduction. London: J. Baker.

INCUNA. 2002. IV Jornadas Internacionales de Patrimonio Industrial: Estructuras y Paisajes Industriales: Proyectos Socio-Culturales y Turismo Industrial. Gijón, Spain: INCUNA.

Koolhaas, R. 2002. Junkspace. Special Issue on “Obsolescence.” October 100: 175-190.

Kuusisto, A.-K. 1999. Politics of Place and Resistance: The Case of Northern Ireland. In NGP Yearbook 1999, edited by J. Vuolteenaho and T. A. Äikas, 15-27. Nordia Geographical Publications 28 (2). [http://cain.ulst.ac.uk/issues/identity/kuusisto99.htm\#nireland].

Liesch, M. 2011. Partnerships and Photographs: Community Conceptions of Keweenaw National Historical Park. Geographical Review 101 (4): 497-517.

Magnaghi, A. 2005. The Urban Village: A Charter for Democracy and Local Self-Sustainable Development. Translated by D. Kerr. London: Zed Books.

Marazzi, C. 2010. The Violence of Financial Capitalism. Translated by K. Lebedeva. New York: Semio$\operatorname{text}(\mathrm{e})$.

Martínez, J. M., and F. Closa. 1999. L'arqueologia industrial: Una visió a la fi del millenni. Revista d'Arqueologia de Ponent 9: 325-335.

McDowell, S. 2008. Heritage, Memory and Identity. In The Ashgate Research Companion to Heritage and Identity, edited by B. Graham and P. Howard, 37-53. Aldershot, U.K.: Ashgate.

Nogué, J. 2007. La construcción social del paisaje. Madrid: Biblioteca Nueva.

Nora, P. 1989. Between Memory and History: Les lieux de mémoire. Special Issue on "Memory and Counter-Memory. Representations, No. 26: 7-24.

Ortega Valcárcel, J. 1998. El patrimonio territorial: El territorio como recurso cultural y económico. Ciudades: Revista del Instituto Universitario de Urbanistica de la Universidad de Valladolid, No. 4: $33-48$.

Pardo Abad, C. J. 2010. El patrimonio industrial en España: Análisis turístico y significado territorial de algunos proyectos de recuperación. Boletín de la Asociación de Geógrafos Españoles, No. 53: 239-266.

Pardo Abad, C. J., and A. Olivera. 1992. Les friches industrielles à Madrid: Opportunités urbanistiques et réutilisation du sol urbain. Révue Belge de Géographie, No. 51: 195-208.

Pinard, J. 1985. L'archéologie industrielle. Paris: Presses Universitaires de France.

Reyes Téllez, F. 2004. El patrimonio arqueológico industrial en la ciudad histórica. Anales de Arqueología Cordobesa, No. 15: 83-99.

Robertson, D. 2006. Hard as the Rock Itself: Place and Identity in the American Mining Town. Boulder: University Press of Colorado.

Rodríguez Gutiérrez, F. 1992. El patrimonio industrial histórico como recurso para el desarrollo local. Ábaco: Revista de Cultura y Ciencias Sociales, No. 1: 71-78.

Ruiz Ballesteros, E. 1999. La conformación del patrimonio minero en Riotinto. Demófilo, No. 32: 241-260.

Ruiz Ballesteros, E., and M. Hernández Ramírez. 2007. Identity and Community-Reflections on the Development of Mining Heritage Tourism in Southern Spain. Tourism Management 28 (3): 677-687.

Rullani, E. 2009. Knowledge Economy and Local Development: The Evolution of Industrial Districts and the New Role of "Urban Networks." Review of Economic Conditions in Italy, No. 2: 237-284. [www.unicreditreviews.eu/uploads/o4_rullani_ing_237-284.pdf].

Sabaté, J. 2005. De la preservación del patrimonio a la ordenación del paisaje. Identidades: Territorio, Cultura y Patrimonio 1 (1): 15-33.

- 2009. Proyecto de parque patrimonial fluvial del Ter. In Gestión del paisaje: Manual de protección, gestión y ordenación del paisaje, edited by J. Busquets Fábregas and A. Cortina Ramos, 625-632. Barcelona: Ariel. 
Sabaté, J., and P. Benito del Pozo. 2010. Paisajes culturales y proyecto territorial: Un balance de treinta años de experiencia. Identidades: Territorio, Cultura y Patrimonio 2 (1): 2-21. [https://upcommons.upc .edu/revistes/bitstream/2099/10716/1/ID2_Sabate_Benito.pdf].

Sabaté, J., and D. Frenchman. 2001. Projectant l'eix del Llobregat: Paisatge cultural i desenvolupament regional. Barcelona: Universidad Politecnica de Cataluña.

Samuel, R. 1994. Theatres of Memory. London:Verso.

Schein, R. H. 2006. Landscape and Race in the United States. New York: Routledge.

Smith, L. 2006. Uses of Heritage. London: Routledge.

Sobrino, J. 1996. La arquitectura industrial en España: 1830-199o. Madrid: Cátedra.

Thrift, N. 2006. Re-Inventing Invention: New Tendencies in Capitalist Commodification. Economy and Society 35 (2): 279-306.

. 2008. Non-Representational Theory: Space, Politics, Affect. London: Routledge.

Tironi, M. 2009. The Paradoxes of Cultural Regeneration: Artists, Neighbourhood Redevelopment and the "Creative City" in Poblenou, Barcelona. Journal of Urban Regeneration and Renewal 3 (1): 92-105.

Troitiño Vinuesa, M. A. 1998. Patrimonio arquitectónico, cultura y territorio. Ciudades: Revista del Instituto Universitario de Urbanística de la Universidad de Valladolid, No. 4: 95-104.

Vall, P. 2008. Revisión metodológica sobre el planeamiento de un paisaje cultural: El Plan Director Urbanístico de las Colonias del Llobregat. Urban, No. 13: 122-136.

Vercellone, C. 2008. The New Articulation of Wages, Rent and Profit in Cognitive Capitalism. Paper presented at The Art of Rent, a seminar held at School of Business and Management, Queen Mary, University of London. Translated by A. Bove. [www.generation-online.org/c/fc_rent2.htm].

Viejo-Rose, D. 2011. Destruction and Reconstruction of Heritage: Impacts on Memory and Identity. In Heritage, Memory and Identity, edited by H. Anheier and Y. R. Isar, 53-69. Thousand Oaks, Calif.: Sage. 